\title{
SISTEM PENDUKUNG KEPUTUSAN PENENTUAN DAERAH TANAMAN KELAPA SAWIT DENGAN METODE PROMETHEE
}

\author{
Sukri \\ Program Studi Teknik Informatika, Fakultas Teknik, Univbersitas Abdurrab Pekanbaru \\ Jl. Riau Ujung No. 73 Pekanbaru \\ E-Mail : sukri@univrab.ac.id
}

\begin{abstract}
ABSTRAK
Saat ini kelapa sawit bukan hal asing lagi kita dengar, kelapa sawit adalah tanaman yang hampir semua bagian dari tanaman kelapa sawit bisa di manfaatkan seperti buah bisa menghasilkan minyak, sabun, dan produksi lainnya yang bernilai jual tinggi, sehingga banyak para petani atau pengusaha beralih menanan kelapa sawit. Untuk menanam kelapa sawit bukan semudah menanam tanaman lainnya karena salah memilih lokasi bisa mengurangi hasil produksi. Selama ini proses penentuan daerah tanaman kelapa sawit dilakukan dengan cara konsultasi dan membandingkan daerah mana yang paling cocok untuk penanaman kelapa sawit dengan mempertimbangkan persentase yang paling bagus untuk penanaman kelapa sawit dengan hitungan dan pilihan urutan prioritas secara menual. Hal ini terkadang memakan waktu yang cukup lama dan tingkat ketelitian kurang bagus dalam mengambil keputusan. Aplikasi ini menggunakan metode waterfall dan teknik pengambilan keputusan Promethee (Preference Rangking Organization Method For Enrichment Evaluation) yang merupakan suatu metode penentuan urutan (prioritas) dalam analisis multikriteria. Kriteria yang digunakan adalah Bibit, Iklim, Tanah, Administrasi, Hama, dan bentuk wilayah. Aplikasi ini memberikan solusi permasalahan yang timbul khususnya penentuan daerah tanaman kelapa sawit. Dengan menggunkan teknik pengambilan keputusan promethee dapat membantu para petani atau pengusaha pengambilan keputusan berdasarkan hasil parameter yaitu rangking dan persentase setiap kabupaten atau alternatif.
\end{abstract}

Kata Kunci: Sistem Pendukung Keputusan, Daerah, Kelapa Sawit, Promethee

\begin{abstract}
ABSTRACK
Currently palm oil is not a stranger to hear, palm oil is a plant that almost all parts of the plant oil palm can be utilized such as fruit can produce oil, soap, and other production high value, so that many farmers or entrepreneurs switch menanan Palm oil. To grow palm oil is not as easy as other crops because one can choose the location to reduce production. During this process of determining the area of oil palm trees is done by consulting and comparing which areas are most suitable for oil palm cultivation by considering the percentage of the most good for the cultivation of oil palm with the count and the selection order of priorities menual. It sometimes takes a long time and the level of accuracy is less good in making decisions. This application uses the method waterfall and decision-making techniques Promethee (Preference Ranking Organization Method For Enrichment Evaluation) is a method of determining the order (priority) in the analysis of multiple criteria. The criteria used were seeds, Climate, soil, Administration, Hama, and the shape of the region. This application provides solutions to problems arising in particular the determination of the area of oil palm. By using PROMETHEE decision-making techniques can help farmers or businessmen decisions based on the parameters of the ranking and the percentages of each district or alternatives.
\end{abstract}

Keywords: Decision Support Systems, Regional, Oil Palm, Promethee

\section{PENDAHULUAN}

Pada dasarnya pengambilan keputusan adalah suatu pendekatan sistematis pada hakikat suatu masalah, pengumpulan fakta-fakta, penentuan yang matang dari arternatif yang dihadapi, dan pengambilan tindakan yang menurut perhitungan merupakan tindakan yang paling tepat.
Pembuat keputusan sering kali dihadapkan pada kerumitan untuk memilih satu diantara banyak alternatif, masalah ini sering terjadi dikehidupan manusia sehari-hari. salah satunya yang dibahas pada penelitian ini adalah masalah petani atau pengusaha yang mengalami kesulitan dalam memilih daerah tanam kelapa sawit. Untuk memecahkan 
masalah tersebut bisa dilakukan dengan survey atau mencari informasi data yang akan diaplikasikan terhadap masing-masing lahan dengan kriteria-kriteria yang ditentukan dengan tujuan untuk memilih lahan atau lokasi yang cocok untuk penanaman kelapa sawit.

Promethee adalah suatu metode penentuan urutan (prioritas) dalam analisis multikriteria. Masalah pokoknya adalah kesederhanaan, kejelasan, dan kestabilan. Dugaan dari dominasi kriteria yang digunakan dalam promethee adalah penggunaan nilai dalam hubungan outranking.

Untuk membantu para petani atau pengusaha agar dapat memilih lahan penanaman kelapa sawit yang baik dan cocok, maka dirancang suatu software yang bisa membantu para petani didalam mengambil keputusan untuk memilih satu dari beberapa arternatif pilihan lahan atau lokasi yang cocok penanaman kelapa sawit.

Pemilihan daerah tanaman kelapa sawit untuk para petani atau pengusaha harus dicermati dengan baik dan tepat karena bisa mempenaruhi kualitas produksi, keamanan dan peningkatan waktu yang harus efektif untuk menghasilkan sampai berproduksi dimana setiap daerah tidak sama. Apabila salah satu faktor tersebut dirasakan kurang baik oleh petani atau pengusaha maka ada kemungkinan peningkatan produktifitas petani atau pengusaha akan menurun dari hasil sebenarnya.

\section{Perumusan Masalah}

Berdasarkan latar belakang permasalahan maka rumusan masalahnya adalah bagaimana membangun suatu sistem pendukung keputusan yang dapat membantu para petani atau pengusaha untuk memberikan saran sebagai bahan pertimbangan untuk memilih suatu daerah penanaman kelapa sawit secara langsung dan objektif dengan menggunakan teknik pengambilan keputusan promethee.

\section{Batasan Masalah}

Agar penelitian ini dapat mencapai sasaran dan tujuan yang diharapkan maka diberikan batasan masalah sebagai berikut :

1. Kriteria yang digunakan sebagai pembanding yang telah dikembangkan, yaitu : Iklim, Tanah dan topologi, Bibit, Bentuk wilayah, Administrasi, dan Hama.

2. Kritera-kriteria yang ditetapkan sebagai pilihan optional dari berbagai alternatif yang ada yaitu : Harga, Jarak, Waktu, Letak, Transportasi, Keamanan, dan biaya.

3. Bobot setiap kriteria adalah satu yang berarti semua kriteria memiliki tingkat kepentingan yang sama pada saat dibandingkan.

4. Para petani atau pengusaha (User) juga dapat memasukkan parameter-parameter dari kriteria yang telah ditentukan.

5. Sistem ini akan memfokuskan pada parameter-parameter yang telah dimasukkan oleh para petani atau pengusaha. Parameter tersebut berupa kriteria yang ingin dibandingkan dengan parameter lainnya.

\section{Tujuan}

Tujuan yang ingin dicapai adalah menghasilkan sebuah software yang dapat membantu para petani atau pengusaha kelapa sawit menentukan keputusan akhir dalam memilih daerah tanam kelapa sawit yang paling cocok dan memuaskan. Disamping itu menerapkan dan mengembangkan model aplikasi Sistem Pendukung Keputusan dengan teknik pengambilan keputusan promethee. 


\section{Manfaat Penelitian}

Manfaat yang diperoleh dari penelitian ini adalah:

1. Aplikasi penentuan daerah tanaman kelapa sawit ini dapat membantu para petani atau pengusaha untuk memilih daerah yang terbaik untuk cocok tanam kelapa sawit berdasarkan survey .

2. Memudahkan para petani atau pengusaha dalam memperoleh informasi pemilihan daerah alternatif untuk penanaman kepala sawit.

\section{Pengambilan Keputusan}

Menurut Simon, ada empat tahap yang harus dilalui dalam proses pengambilan keputusan (Daihani, 2001), yaitu:

1. Tahap Penulusuran (Intelligence), merupakan tahap pendefinisian masalah serta identifikasi informasi yang dibutuhkan yang berkaitan dengan persoalan yang dihadapi serta keputusan yang akan diambil. Langkah inin sangat memerlukan tingkat ketepatan keputusan yang akan diambil, karena sebelum suatu tindakan diambil, tentunya persoalan yang dihadapi harus dirumuskan terlebih dahulu secara jelas.

2. Tahap Perancangan (design), merupakan tahap analisa dalam kaitan mencari atau merumuskan alternative-alternatif pemecahan masalah. Setelah permasalahan dirumuskan dengan baik,maka tahap berikutnya adalah merancang atau membangun model pemecahan masalahnya dan menyusun berbagai alternative pemecahan masalah.

3. Pemilihan (choice), dengan mengacu pada rumusan tujuan serta hasil yang diharapkan selanjutnya manajemen memilih alternatif solusi yang diperkirakan paling sesuai. Pemilihan alternatif ini akan mudah dilakukan kalau hasil yang diinginkan terukur atau memiliki nilai kuantitas tertentu.
4. Implementasi

(implementation), merupakan tahap pelaksanaan dari keputusan yang telah diambil. Pada tahap ini perlu disusun serangkaian tindakan yang terencana, sehingga hasil keputusan dapat dipantau dan disesuaikan apabila diperlukan perbaikanperbaikan.

\section{Sistem Pendukung Keputusan}

Menurut definisi Little, McLeod, Man dan Watson Sistem Pendukung Keputusan adalah suatu sistem informasi spesifik yang ditujukan untuk membantu manajemen dalam mengambil keputusan yang berkaitan dengan persoalan yang semi terstruktur dan tidak terstruktur (Daihani, 2001). Sistem ini memiliki fasilitas untuk menghasilkan berbagai alternatif yang secara interaktif dapat digunakan oleh pemakai. Kata berbasis komputer merupakan kata kunci, karena hampir tidak mungkin membangun SPK tanpa memanfaatkan komputer sebagai alat bantu terutama untuk menyimpan data serta mengolah model. Kata kunci lainnya adalah penggunaan model-model keputusan sebagai dasar pengembangan alternatif. Penggunaan model ini berkaitan dengan sifat permasalahan yang harus dipecahkan pemakai yaitu semi terstruktur atau tidak terstruktur.

\section{a. Karakteristik Sistem Pendukung Keputusan}

Beberapa karakteristik yang membedakan SPK dengan sistem informasi lainnya, yaitu :

1. Sistem Pendukung Keputusan dirancang untuk membantu pengambil keputusan dalam memecahkan masalah yang sifatnya semi terstruktur ataupun tidak terstruktur.

2. Dalam proses pengolahannya, sistem pendukung keputusan mengombinasikan model-model analisis dengan teknik 
pemasukan data konvensional serta fungsifungsi pencarian informasi.

3. Sistem Pendukung Keputusan, dirancang sedemikian rupa sehingga dapat digunakan/dioperasikan dengan mudah oleh orang-orang yang tidak memiliki dasar kemampuan pengoperasian komputer yang tinggi. Oleh karena itu pendekatan yang digunakan biasanya model interaktif.

4. Sistem Pendukung Keputusan dirancang dengan menekankan pada aspek fleksibilitas serta kemampuan adaptasi yang tinggi. Sehingga mudah disesuaikan dengan berbagai perubahan lingkungan yang terjadi dan kebutuhan pemakai

b. Komponen Sistem Pendukung Keputusan

Sistem Pendukung Keputusan terdiri dari tiga subsistem utama, yaitu :

1. Subsistem manajemen data/basis data.

2. Subsistem manajemen model/basis model.

3. Subsistem penyelenggara dialog.

Hubungan antara ketiga komponen ini dapat dilihat pada gambar 1 berikut (Suryadi, 2002) :

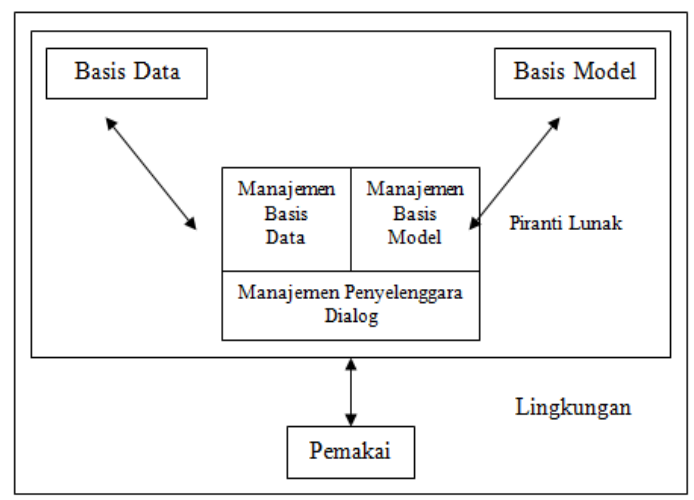

Gambar 1. Komponen Utama Sistem Pendukung Keputusan

Keterangan Gambar 1:

1. Subsistem manajemen data/basis data

Subsistem manajemen data merupakan komponen SPK penyedia data bagi sistem. Data pada basis data SPK diekstrak dari sumber data internal dan eksternal, juga dari data personal milik satu atau lebih pengguna, kemudian hasil ekstraksi ditempatkan pada basis data SPK. Data internal berasal terutama dari sistem pemrosesan transaksi dari organisasi. Data eksternal contohnya data industri, data riset pemasaran, dan data pertanian. Data personal dapat meliputi petunjuk-petunjuk yang digunakan oleh pengambil keputusan khusus dan penilaian terhadap data atau situasi spesifik.

Pada dasarnya ekstraksi berisi file-file penting, rangkuman, filtrasi standarisasi, dan kondensasi data. Ekstraksi juga terjadi ketika pengguna menghasilkan laporan-laporan dari data di dalam basis data SPK.

2. Subsistem manajemen model/basis model

Model merupakan representasi atau abstraksi sederhana dari realitas. Model dapat merepresentasikan sistem atau masalah dengan berbagai tingkatan abstraksi. Model dalam basis model terdiri dari model strategis, model taktis, dan model operasional. Selain itu juga terdapat blok pembangun model dan subrutin. Model strategis digunakan untuk mendukung manajemen puncak untuk menjalankan tanggung jawab perencanaan strategis. Model taktis digunakan terutama oleh manajemen tingkat menengah untuk membantu mengalokasikan dan mengontrol sumber daya organisasi. Model operasional digunakan untuk mendukung aktivitas kerja harian organisasi. Sedangkan blok pembangunan model dapat disebarkan untuk aplikasi sebagai analisis data. Beberapa blok pembangunan ini dapat digunakan untuk menentukan nilai variabel dan parameter pada suatu model.

Subsistem manajemen model

merupakan paket perangkat lunak yang memasukkan model keuangan, statistik, ilmu manajemen, atau model kuantitatif lainnya yang memberikan kapabilitas analitik dan 
manajemen. Perangkat lunak ini sering disebut sistem manajemen basis model (Model Base Management System/ MBMS). Fungsi dari MBMS adalah untuk membuat model dengan menggunakan bahasa pemrograman, alat SPK dan subrutin, dan blok pembangunan lainnya.

\section{Subsistem penyelenggara dialog}

Subsistem dialog adalah fasilitas yang mampu mengintegrasikan sistem terpasang dengan pengguna secara interaktif. Melalui sistem dialog inilah sistem diartikulasikan dan diimplementasikan sehingga pengguna atau pemakai dapat berkomunikasi dengan sistem yang dirancang. Subsistem dialog ini dikelola oleh perangkat lunak yang disebut sistem manajemen antarmuka pengguna (User Interface Management System/UIMS).

Subsistem dialog terbagi menjadi tiga komponen yaitu (Suryadi, 2002) :

a. Bahasa aksi, meliputi apa yang dapat digunakan pengguna untuk berkomunikasi dengan sistem. Komunikasi ini dilakukan melalui berbagai pilihan media seperti keyboard, joystick, panel sentuh, perintah suara dan sebagainya.

b. Bahasa tampilan atau presentasi, meliputi sarana yang berfungsi untuk menampilkan sesuatu yang harus diketahui pemakai. Peralatan yang digunakan untuk merealisasikan tampilan ini di antaranya adalah printer, layar tampilan, grafik monitor, plotter, keluaran suara dan lainlain.

c. Basis pengetahuan, meliputi bagian yang mutlak diketahui oleh pengguna sehingga sistem yang dirancang dapat berfungsi secara efektif. Basis pengetahuan bisa berada dalam pikiran pemakai, pada kartu referensi atau petunjuk, dalam buku manual dan sebagainya.
Promethee adalah suatu metode penentuan urutan (prioritas) dalam analis multikriteria. Masalah pokoknya adalah keserhanaan, kejelasan dan kesetabilan. (Kadarsah,1998).

Dugaan dari dominasi kriteria yang digunakan dalam promethee adalah menggunakan nilai dalam outranking. Prinsip yang digunkan adalah penetapkan prioritas alternatif yang telah ditetapkan berdasarkan pertimbangan :

$\{(\forall \mathrm{i} \mid \mathrm{fi}(.) \rightarrow \mathfrak{R}$ [real world] $\}$

Dengan kaidah dasar :

Dimana $\mathrm{K}$ adalah sejumlah kumpulan alternatif, dan fi $(i=1,2, . ., \mathrm{K})$ merupkan nilai atau ukuran relatif kriteria untuk masingmasing alternatif.

Promethee termasuk dalam keluarga dari metode outrangking yang meliputi dua fase :

1. Membangun hubungan outrangking dari $\mathrm{K}$ (sejumlah kumpulan alternatif).

2. Ekploitasi dari hubungan ini memberikan jawaban optimasi kriteria dalam pradigma permasalahan multikriteria.

Dalam fase pertama, nilai hungan outrangking berdasarkan pertimbangan dominasi masingmasing kriteria. Indeks preferensi ditentukan dan nilai outrangking secara grafis disajikan berdasarkan preferensi dari pembuat keputusan. Data dasar untuk evaluasi dengan metode promethee disajikan sebagai berikut :

Tabel 1. Data Dasar Analisis Promethee

\begin{tabular}{lllllll}
\hline & F1 & F2 & $\ldots$. & Fj (.) & $\ldots$ & Fk \\
& $()$. & $()$. & & &. & $()$. \\
\hline A1 & F1 & F2 & $\ldots$. & Fj & $\ldots$ & Fk \\
A2 & $(\mathrm{a} 1)$ & $(\mathrm{a} 1)$ & $\ldots$ & (a1) &. & (a1) \\
$\ldots$. & F1 & F2 & $\ldots$ & Fj & $\ldots$ & Fk \\
Ai & (a2) & (a2) & $\ldots$ & (a2) &. & (a2) \\
$\ldots$. & $\ldots$. & $\ldots$. & $\ldots$ & $\ldots$ & $\ldots$ & $\ldots$. \\
An & F1 & F2 & $\ldots$. & Fj &. & Fk \\
& (ai) & (ai) & & (ai) & $\ldots$ & (ai) \\
\hline
\end{tabular}




\begin{tabular}{lllll}
\hline$\ldots$. & $\ldots$. & $\ldots \ldots .$. &. & $\ldots$. \\
F1 & F2 & Fj & $\ldots$ & Fk \\
$($ an $)$ & (an) & (an) &. & (an) \\
& & & $\ldots$ & \\
& & &. & \\
\hline
\end{tabular}

Struktur preferensi yang dibangun atas dasar kriteria :

$$
; \forall \mathrm{a}, \mathrm{b} \in \mathrm{A} \quad \rightarrow \mathrm{f}(\mathrm{a})>\mathrm{f}(\mathrm{b}) \Leftrightarrow \mathrm{aP} \mathrm{b}
$$$$
\mathrm{f}(\mathrm{a}), \mathrm{f}(\mathrm{b}) \rightarrow \mathrm{f}(\mathrm{a})>\mathrm{f}(\mathrm{b}) \Leftrightarrow \mathrm{a} \text { I b }
$$

\section{a. Dominasi Kriteria}

Nilai f merupakan nilai nyata dari suatu kriteria $: f: \mathrm{K} \rightarrow \mathfrak{R}$ dan tujuan berupa prosedur optimasi.

Untuk setiap alternatif a $\in \mathrm{K}, f$ (a) merupakan evaluasi dari alternatif tersebut untuk suatu kriteria. Pada saat dua alternatif dibandingkan, $\mathrm{a}, \mathrm{b} \in \mathrm{K}$, harus dapat ditentukan perbandingan preferensinya.

Penyampaian intensitas (P) dari preferensi alternatif a terhadap alternatif $b$ sedemikian rupa sehingga :

$2 \mathrm{P}(\mathrm{a}, \mathrm{b})=0$, berarti tidak ada beda (indifferent) antara a dan $b$, atau tidak ada preferensi dari a lebih baik dari b.

$3 \mathrm{P}(\mathrm{a} . \mathrm{b}) \approx 0$, berarti lemah preferensi dari a lebih baik dari $b$.

$4 \mathrm{P}(\mathrm{a}, \mathrm{b}) \approx 1$, berarti kuat preferensi dari a lebih baik dari $b$.

$5 \quad \mathrm{P}(\mathrm{a}, \mathrm{b})=1$, berarti mutlak preferensi dari a lebih baik dari $b$.

Dalam metode ini, fungsi preferensi seringkali menghasilkan nilai fungsi yang berbeda antara dua fungsi, sehingga : $\mathrm{P}(\mathrm{a}, \mathrm{b})=$ $\mathrm{P}(\mathrm{f}(\mathrm{a})$ - $\mathrm{f}(\mathrm{b})$. Untuk kasus semua kriteria, suatu alternatif yang akan dihitung dengan perhitungan kriteria total suatu alternatif ditentukan oleh nilai $f$ dan akumulasi dari nilai ini menentukan nilai preferensi atas masingmasing alternatif yang akan dipilih.

\section{b. Fungsi Preferensi}

Dalam Promethee disajikan enam bentuk fungsi preferensi kriteria. Hal ini tentu saja tidak mutlak, tetapi bentuk ini cukup baik untuk beberapa kasus.

Untuk memberikan gambaran yang lebih baik terhadap area yang tidak sama, digunakan fungsi selisih nilai kriteria antar alternatif $\mathrm{H}(\mathrm{d})$ dimana hal ini mempunyai hubungan langsung pada fungsi preferensi $P$ : $\left.\begin{array}{l}\forall \mathrm{a}, \mathrm{b} \in \mathrm{A} \\ \mathrm{f}(\mathrm{a}), \mathrm{f}(\mathrm{b})\end{array}\right\} \begin{array}{r}\mathrm{f}(\mathrm{a})>\mathrm{f}(\mathrm{b}) \Leftrightarrow \mathrm{a} \text { P } \mathrm{b}(\mathrm{a})=\mathrm{f}(\mathrm{b}) \Leftrightarrow \mathrm{a} \text { I } \mathrm{b} \text { (a Indifferent } \mathrm{b}) \\ \text { (a) })\end{array}$ Melalui analisis pengambilan keputusan kriteria majemuk, setiap hubungan preferensi antar alternatif dibandingkan hasil antara, lebih disukainya suatu alternatif ( $\mathrm{P}=$ prefer), tidak berbeda ( $\mathrm{I}=$ Indifferent).

1. Kriteria Biasa (Usual Criterion)

Rumus preferensi kriteria biasa :

$H(d)=\left\{\begin{array}{l}0 \text { jika } d=0 \\ 1 \text { jika } d \neq 0\end{array}\right.$

Dimana $\mathrm{d}=$ selisih nilai kriteria $\{\mathrm{d}=f(\mathrm{a})-$ $f(\mathrm{~b})\}$

Pada kasus ini, tidak ada beda (sama penting) antara a dan $\mathrm{b}$ jika dan hanya jika $f(\mathrm{a})=f(\mathrm{~b})$; apabila nilai kriteria pada masing-masing alternatif memiliki nilai berbeda, pembuat keputusan membuat preferensi mutlak untuk alternatif yang memiliki nilai yang lebih baik.

2. Kriteria Quasi (Quasi Criterion)

Rumus preferensi kriteria quasi :

$H(d)=\left\{\begin{array}{l}0 \text { jika }-\mathrm{q} \leq \mathrm{d} \leq \mathrm{q} \\ 1 \text { jika } \mathrm{d}<-\mathrm{q} \text { atau } \mathrm{d}>\mathrm{q}\end{array}\right.$

Dua alternatif memiliki preferensi yang sama penting selama selisih atau nilai $\mathrm{H}(\mathrm{d})$ dari masing-masing alternatif untuk kriteria tertentu tidak melebihi nilai q, dan apabila selisih hasil evaluasi untuk masing-masing alternatif melebihi nilai q maka terjadi 
preferensi mutlak. Sedangakan q adalah batasan atau parameter pertama.

3. Kriteria dengan preferensi linier

Rumus preferensi kriteria linier :

$H(d)=\left\{\begin{array}{l}d / p \text { jika }-p \leq d \leq p \\ 1 \text { jika } d<- \text { atau } d>p\end{array}\right.$

Selama nilai selisih memiliki nilai yang lebih rendah dari $\mathrm{p}$ (parameter kedua), preferensi dari pembuat keputusan meningkat secara linier dengan nilai d. Jika nilai d lebih besar dibandingkan nilai $\mathrm{p}$ (parameter kedua), maka terjadi preferensi mutlak.

4. Kriteria Level (Level Criterion)

Rumus preferensi kriteria level :

$H(d)= \begin{cases}0 & \text { Jika }|\mathrm{d}| \leq \mathrm{q}, \\ 0,5 & \text { Jika } \mathrm{q}<|\mathrm{d}| \leq \mathrm{p}, \\ 1 & \text { Jika } \mathrm{p}<|\mathrm{d}|\end{cases}$

Dalam kasus ini, kecenderungan tidak berbeda $\mathrm{q}$ dan kecenderungan preferensi $\mathrm{p}$ adalah ditentukan secara simultan. Jika d berada di antara nilai $\mathrm{q}$ dan $\mathrm{p}$, hal ini berarti situasi preferensi yang lemah $(\mathrm{H}(\mathrm{d})=0,5)$.

5. Kriteria dengan preferensi linier dan area yang tidak berbeda

Rumus preferensi kriteria linier dan area yang tidak berbeda :

$$
\mathrm{H}(\mathrm{d})=\left\{\begin{array}{l}
0 \text { jika }|\mathrm{d}| \leq \mathrm{q}, \\
(|d|-q) /(p-q) \text { jika } \mathrm{q}<|\mathrm{d}| \leq \mathrm{p}, \\
1 \text { jika } \mathrm{p}<|\mathrm{d}|
\end{array}\right.
$$

Pengambil keputusan mempertimbangkan peningkatan preferensi secara linier dari tidak berbeda hingga preferensi mutlak dalam area antara dua kecenderungan $\mathrm{q}$ dan $\mathrm{p}$.

6. Kriteria Gaussian (Gausian criterion)

Rumus preferensi kriteria gaussian :

$\mathrm{H}(\mathrm{d})=1-\exp \left\{-\mathrm{d}^{2} / 2 \sigma^{2}\right\}$

Fungsi ini bersyarat apabila telah ditentukan nilai $\sigma$, dimana dapat dibuat berdasarkan distribusi normal dalam statistik.

\section{Kelapa Sawit}

Kelapa sawit adalah tumbuhan yang hampir semua bagiannya menghasilkan nilai guna yang terdiri dari beberapa bagian yaitu daging buah, biji sawit, tandan kosong, dan batang sawit. (Suyatno,1995).

\section{Asal-usul Kelapa Sawit}

Berdasarkan bukti-bukti yang ada, kelapa sawit diperkirakan berasal dari Negeria, Afrika Barat. Namun adapula yang menyatakan bahwa tanaman tersebut berasal dari Amerika, yakni dari Brazilia. Zeven menyatakan bahwa tanaman kelapa sawit berasal dari daratan tersier, yang merupakan daratan penghubung yang terletak diantara Afrika dan Amerika. Kedua daratan ini kemudian terpisah oleh lautan menjadi benua Afrika dan Amerika sehingga asal tempat komonitas kelapa sawit ini tidak dipermasalahkan orang.

Kelapa sawit (Elaeis guineesis), saat ini telah berkembang pesat di Asia Tenggara, khususnya Indonesia dan Malaysia, dan justru bukan di Afrika Barat atau Amerika yang dianggap sebagai daerah asal nya. Masuknya bibit kelapa sawit ke Indonesia pada tahun 1948 hanya sebanyak 4 batang yang berasal dari Bourbon (Mauriyius) dan Amsterdam. Ke-empat batang bibit kelapa sawit tersebut ditanam di Kebun Raya Bogor dan selanjutnya disebarkan ke Deli Sumatra Utara (Suyatno, 1995).

\section{Jenis-Jenis Kelapa Sawit}

Terdiri dari tiga jenis Kelapa sawit di Indonesia, yaitu (Suyatno,1995):

1. Dura

Ciri-ciri :

a. Daging buah tipis (20-65\%)

b. Tempurung tebal (20-50\%)

c. Biji tebal (3-8\%) 
2. Pisifera

Ciri-ciri :
a. Daging buah tebal (92-97\%)
b. Tidak ada tempurung
c. Biji tebal (3-8\%)

3. Tenera

Ciri-ciri :
a. Kandungan minyak tinggi
b. Daging buah sedang (60-96\%)
c. Tempurung tipis (3-20\%)
d. Biji sedang (3-15\%)

\section{Syarat Pertumbuhan Kelapa Sawit}

Dalam meningkatkan produksi dan daya tahan pertumbuhan kelapa sawit sangat tergantung terhadap iklim, keadaan tanah, bentuk wilayah, dan pengaruh terhadap hama dan penyakit. Sedangkan faktor pendukung untuk meningkatkan potensi kerjasama dan keamanan lingkungan diperlukan administrasi yang jelas (Suyatno,1995).

1. Keadaan Iklim

a. Secara alami kelapa sawit hanya dapat tumbuh di daerah tropis. Tanaman ini dapat tumbuh ditempat berawa (swamps) di sepanjang bantaran sungai dan di tempat yang basah.

b. Didalam hutan hujan tropis, tanaman ini tidak dapat tumbuh karena terlalu lembab dan tidak mendapat sinar matahari karena ternaungi kanopi tumbuhan yang lebih tinggi.

c. Sinar matahari harus langsung mengenai daun kelapa sawit. Lama penyinaran matahari rata-rata 5-7 jam perhari.

d. Angin tidak mempengaruhi pertumbuhan karena bentuk daun yang sedemikian rupa sehingga tidak mudah dirusak angin. e. Benih kelapa sawit mengalami dormansi (keadaan sementara tanaman) yang cukup panjang.

f. Diperlukan aerasi yang baik dan temperatur yang tinggi untuk memutuskan masa dormansi agar bibit dapat berkecambah.

g. Pada proses perkecambahan diperlukan kelembaban $\quad 60-80 \% \quad$ dengan temperatur $35^{\circ} \mathrm{C}$.

h. Curah hujan tahunan antara 1.500$4.000 \mathrm{~mm}$, optimal 2.000-3.000 $\mathrm{mm} /$ tahun.

2. Keadaan Tanah

a. Tanah yang baik untuk budidaya kelapa sawit harus mengandung banyak lempung, beraerasi baik dan subur.

b. Tanah harus berdrainase baik, permukaan air tanah cukup dalam, solum cukup dalam, tidak berbatu.

c. Tanah Latosol, Ultisol dan Aluvial yang meliputi tanah gambut, dataran pantai dan muara sungai dapat dijadikan perkebunan kelapa sawit.

d. Tanah memiliki derajat keasaman $(\mathrm{pH})$ antara 4-6.

e. Ketinggian tempat yang ideal bagi pertumbuhan tanaman kelapa sawit antara 1-400 m dpl.

f. Topografi datar dan berombak sampai bergelombang.

g. Kelerengan ideal berkisar antara 0 sampai $25 \%$.

3. Bentuk Wilayah
a. Lereng 0-15\%
b. Tidak ada Rawa
c. Tidak ada penggenangan atau banjir
d. Tidak ada drainase
e. Tidak ada pengaruh pasang surut

4. Hama

a. Kumbang penggerak 

b. Tikus
c. Tirathaba sp
d. Rayap
e. Babi hutan
f. Gajah
g. Landak
h. Ulat pemakan daun

\section{METODE}

\section{Analisis Kebutuhan}

Tahap analisis kebutuhan merupakan tahap awal pada suatu penelitian tahap ini dilakukan dengan melihat latar belakang dari penelitian, kemudian melihat batasan masalah dan selanjutnya melakukan perancangan sistem pendukung keputusan agar dapat digunakan dan dapat memberikan keputusan pendukung yang akan dibuat.

\section{Spesifikasi}

Spesifikasi adalah pengumpulan data merupakan langkah kedua dalam melakukan penelitian. Data dikumpulkan dari berbagai sumber yang ada. Pengumpulan data pada penelitian ini dilakukan dengan 2 metode yaitu metode wawancara dan studi pustaka (literature).

\section{Perancangan Sistem}

Merupakan tahap penulisan proses data, aliran proses dan hubungan antar data yang paling optimal dan memenuhi kebutuhan pihak yang sesuai dengan hasil analisa kebutuhan.

1. Perancangan Proses

2. perancangan Basis Data

3. Perancangan Tabel

4. Perancangan Antar Muka

\section{Implementasi dan Pengujian Sistem}

Pada tahap ini penulis menguji berdasarkan rancangan yang telah dibuat sebelumnya sesuai dengan kebutuhan pihak terkait. Dan tahap pengujian terhadap sistem yang telah dibuat sekaligus mengevaluasi kekurangan serta kelebihan sistem tersebut.

\section{Pemeliharaan}

Tahap ini dilakukan guna mengevaluasi sistem yang telah dibuat untuk memperoleh hasil yang optimal, dan perawatan terhadap system dengan tujuan agar sistem yang sudah terpasang dapat berjalan semakin efektif dan efisien, perawatan sistem baru harus dilakukan secara berturut turut dan terencana. Apabila program terdapat error, maka akan diadakan perbaikan pada program dengan cara memperbaiki dan menghilangkan error yang terjadi sampai program dapat digunakan dengan baik dan sempurna.

\section{HASIL}

\section{Analisis Sistem}

Para petani atau pengusaha sering kali dihadapkan pada permasalahan pemilihan lokasi atau daerah penanaman kelapa sawit yang cocok, seperti letak dan tinggi tempat, strategis wilayah dan sebagainya. Untuk membantu memecahkan masalah itu maka penulis membuat suatu sistem pendukung keputusan untuk memilih wilayah atau daerah khususnya untuk penanaman kelapa sawit yang mana sistem pendukung keputusan ini menggunakan metode promethee.

Kriteria-kriteria utama yang ditetapkan sebagai penentu pilihan dari berbagai kabupaten yang ada adalah :
1. Iklim
2. Hama
3. Bentuk Wilayah
4. Tanah dan topologi
5. Bibit 
6. Administrasi

Kritera-kriteria yang ditetapkan sebagai pilihan optional dari berbagai kabupaten yang ada adalah :

1. Harga

2. Jarak

3. Waktu

4. Letak

5. Transportasi

6. Keamanan

7. Biaya

Untuk membantu menemukan jalan keluar bagi para petani maka dibuat suatu sistem yang dapat menentukan urutan (prioritas) dalam analisis multikriteria dan memberikan informasi mengenai daerah tanam yang akan di tanam kelapa sawit dan menentukan urutan berdasarkan kriteria yang ditentukan sendiri.

\section{Spesifikasi Sistem}

Aplikasi penentuan daerah tanam kelapa sawit dengan metode promethee ini memiliki spesifikasi sebagai berikut :

1. Sistem memberikan fasilitas untuk pengaturan data pengguna sistem.

2. Sistem memberikan fasilitas untuk pengelolaan data pemilihan daerah tanam kelapa sawit seperti menambah data, mengubah dan menghapus data.

3. Sistem memberikan fasilitas untuk input daerah atau kabupaten, input kriteria utama, input kriteria optional, dan input data input data preferensi.

4. Sistem memberikan fasilitas untuk menghitung ulang kualitas layanan.

5. Sistem mampu untuk menampilkan data preferensi, data nilai prioritas serta data nilai konsistensi.

\section{Arsitektur Sistem}

Dalam membangun sistem pendukung keputusan penentuan daerah tanam kelapa sawit, diperlukan arsitektur sistem seperti pada gambar 2 berikut ini.

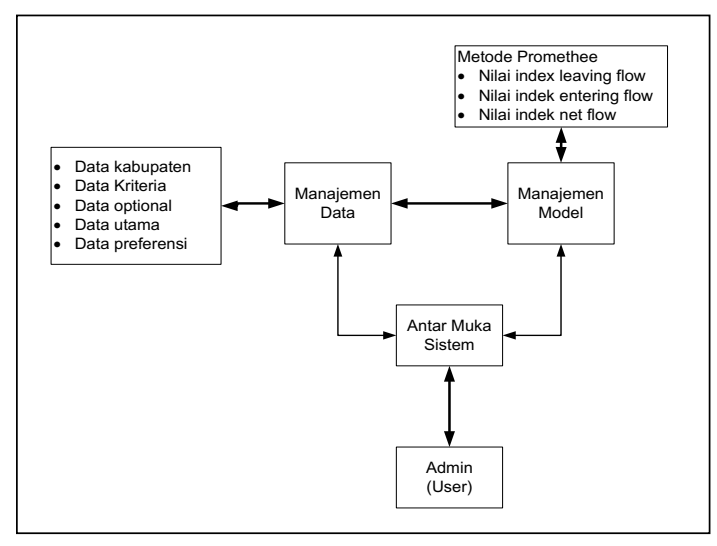

Gambar 2. Arsitektur Sistem

Manajemen data bertujuan untuk mengelola data pada aplikasi SPK. Data aplikasi ini dalam bentuk database yang berisi data yang relevan dengan situasi dan dikelola oleh software DBMS yang mempunyai fasilitas tambah, dan update.

Manajemen model merupakan paket software yang memuat model financial, statistikal, ilmu manajemen atau model kuantitatif lainnya yang menyediakan kemampuan analisis sistem dan manajemen software yang tepat. Manajemen model yang digunakan dalam sistem adalah metode promethee.

Komunikasi (system interface) berfungsi untuk menghubungkan pengguna dengan aplikasi SPK dan memberi perintah melalui subsistem ini. Subsistem ini menyediakan user system interface.

Manajemen Pengetahuan bersifat optional dan dapat mendukung subsistem lain, atau berdiri sendiri sebagai komponen. sistem pendukung keputusan yang lebih kompleks 
memiliki komponen manajemen ilmu pengetahuan yang memiliki kemampuan menyelesaikan beberapa aspek masalah dan menyediakan pengetahuan untuk meningkatkan operasi komponen sistem pendukung keputusan yang lain.

\section{Rancangan Sistem}

Aplikasi yang akan dibangun adalah aplikasi sistem pendukung keputusan yang menggunakan metode promethee.

\section{Rancangan Model}

Untuk masalah pengukuran serta perbandingan kualitas layanan, dimensi yang digunakan sebagai kriteria meliputi iklim, bibit, tanah adan tepologi, bentuk wilayah, hama dan penyakit serta administrasi. Simbol yang digunakan untuk kriteria tersebut adalah : K1 : bibit

$\mathrm{K} 2$ : iklim

$\mathrm{K} 3$ : tanah

$\mathrm{K} 4$ : administrasi

K5 : hama

K6 : bentuk wilayah

K7 : harga

K8 : Jarak

K9 : Biaya

K10 : Waktu

K11: Keamanan

K12 : Letak

K13 : Transportasi

Simbol Alternatif atau kabupaten yang digunakan adalah :

A1 : Alternatif 1

A2 : Alternatif 2

A3 : Alternatif 3

A4 : Alternatif 4

A5 : Alternatif 5

A6 : Alternatif 6

Simbol hasil perhitungan :

LF : Leaving flow
$\mathrm{EF}:$ Entering flow

NF : Net flow

Berdasarkan data dan hasil dari penelitian laboratorium ilmu tanah jurusan budidaya pertanian fakultas pertanian UNIB dan buku panduan "Upaya Meningkatkan Produktivutas Kelapa Sawit" yang memberikan skala penilaian dengan menggunakan skala perbandingan persentasi berdasarkan kelas-kelasnya, di dalam kelaskelas tersebut terdapat batasan penilain untuk masing-masing sub-sub kriteria dan memberikan tingkatan atau keadaan setiap kelasnya. Untuk menentukan hasil penelitian masing-masing sub-sub kriteria dapat di lihat pada tabel sebagai berikut yaitu:

Tabel 2. Nilai Kriteria

\begin{tabular}{lcccc}
\multirow{2}{*}{ Bibit } & $\begin{array}{c}\text { Kela } \\
\text { s I }\end{array}$ & $\begin{array}{c}\text { Kelas } \\
\text { II }\end{array}$ & $\begin{array}{c}\text { Kela } \\
\text { s III }\end{array}$ & $\begin{array}{c}\text { Kelas } \\
\text { IV }\end{array}$ \\
\hline \multirow{3}{*}{ Tipe } & Baik & Biasa & Aga & Buruk \\
Dura & & & k & \\
& & & bias &
\end{tabular}

bias

\begin{tabular}{|c|c|c|c|c|}
\hline & & & $\mathrm{a}$ & \\
\hline & Baik & Biasa & Aga & Buruk \\
\hline Tipe & & & $\mathrm{k}$ & \\
\hline Pisipera & & & bias & \\
\hline
\end{tabular}

\begin{tabular}{lll}
\multicolumn{3}{c}{ a } \\
\hline Baik Biasa Aga & Buruk
\end{tabular}

Tipe $\mathrm{k}$

Tenera bias

\begin{tabular}{lllll}
\multicolumn{1}{c}{ Iklim } & $\begin{array}{c}\text { Kela } \\
\text { s I }\end{array}$ & $\begin{array}{c}\text { Kelas } \\
\text { II }\end{array}$ & $\begin{array}{l}\text { Kela } \\
\text { s III }\end{array}$ & $\begin{array}{c}\text { Kelas } \\
\text { IV }\end{array}$ \\
\hline $\begin{array}{l}\text { Curah_H } \\
\text { ujan }\end{array}$ & $\begin{array}{l}2000 \\
\text { (mm) }\end{array}$ & $\begin{array}{l}2000- \\
2500 \\
1800\end{array}$ & $\begin{array}{l}1800 \\
1500-\end{array}$ & $\begin{array}{l}1500 \\
0\end{array}$ \\
\hline $\begin{array}{l}\text { Defisit_ } \\
\text { Air } \\
(\mathrm{mm})\end{array}$ & $\begin{array}{l}0- \\
150\end{array}$ & $\begin{array}{l}150- \\
250\end{array}$ & $\begin{array}{l}250- \\
400\end{array}$ & 400 \\
\hline Temperat & $22-$ & $(>24)$ & $20-$ & $(<19)$ \\
\hline
\end{tabular}




\begin{tabular}{lllll}
\hline ur $(\mathrm{C})$ & 23 & & 21 & \\
\hline $\begin{array}{l}\text { Lama } \\
\begin{array}{l}\text { Cahaya } \\
\text { (jam) }\end{array}\end{array}$ & 6 & $(>7)$ & 5 & $(<4)$ \\
\hline $\begin{array}{l}\text { Kelemba } \\
\text { ban } /(\%)\end{array}$ & 80 & 70 & 60 & 50 \\
\hline Tanah & $\begin{array}{l}\text { Kela } \\
\text { s I }\end{array}$ & $\begin{array}{l}\text { Kelas } \\
\text { II }\end{array}$ & $\begin{array}{l}\text { Kela } \\
\text { s III }\end{array}$ & Kelas \\
\hline Erosi & tidak & sediki & ada & banya \\
ada & t & k \\
\hline $\begin{array}{l}\text { Solum } \\
(\mathrm{cm})\end{array}$ & 80 & 70 & $\begin{array}{l}60- \\
70\end{array}$ & $(<60)$ \\
\hline Bahan & & & &
\end{tabular}

\begin{tabular}{|c|c|c|c|c|}
\hline & & 25 & & \\
\hline $\begin{array}{l}\text { Babi_Hu } \\
\tan (\%) /\end{array}$ & $0-15$ & $\begin{array}{l}16 \\
- \\
25\end{array}$ & $25-36$ & $>36$ \\
\hline $\begin{array}{l}\text { Gajah } \\
(\%) / \text { hari }\end{array}$ & $0-15$ & $\begin{array}{l}16 \\
- \\
25\end{array}$ & $25-36$ & $>36$ \\
\hline $\begin{array}{l}\text { Landak } \\
(\%) / \text { hari }\end{array}$ & $0-15$ & $\begin{array}{l}16 \\
- \\
25\end{array}$ & $25-36$ & $>36$ \\
\hline Ulat(\%)/ & $0-15$ & $\begin{array}{l}16 \\
- \\
25\end{array}$ & $25-36$ & $>36$ \\
\hline $\begin{array}{l}\text { Bentuk_- } \\
\text { Wilayah }\end{array}$ & Kelas I & $\begin{array}{l}\mathrm{Ke} \\
\text { las } \\
\text { II }\end{array}$ & $\begin{array}{l}\text { Kelas } \\
\text { III }\end{array}$ & $\begin{array}{l}\text { Kel } \\
\text { as } \\
\text { IV }\end{array}$ \\
\hline $\begin{array}{l}\text { Lereng } \\
(\%)\end{array}$ & $0-15$ & $\begin{array}{l}16 \\
- \\
25\end{array}$ & $25-36$ & $>36$ \\
\hline $\begin{array}{l}\text { Rawa } \\
(\%)\end{array}$ & $0-15$ & $\begin{array}{l}16 \\
- \\
25\end{array}$ & $25-36$ & $>36$ \\
\hline $\begin{array}{l}\text { Banjir(\% } \\
\text { )/bulan }\end{array}$ & $0-15$ & $\begin{array}{l}16 \\
- \\
25\end{array}$ & $25-36$ & $>36$ \\
\hline $\begin{array}{l}\text { Drainase } \\
(\%)\end{array}$ & $0-15$ & $\begin{array}{l}16 \\
- \\
25\end{array}$ & $25-36$ & $>36$ \\
\hline $\begin{array}{l}\text { Pasang_ } \\
\text { Surut } \\
(\%)\end{array}$ & $0-15$ & $\begin{array}{l}16 \\
- \\
25\end{array}$ & $25-36$ & $>36$ \\
\hline
\end{tabular}

\begin{tabular}{|c|c|c|c|c|}
\hline $\begin{array}{l}\text { Keadaan } \\
\text { Batuan }\end{array}$ & $\begin{array}{l}\text { dala } \\
\mathrm{m}\end{array}$ & $\begin{array}{l}\text { sedan } \\
\mathrm{g}\end{array}$ & $\begin{array}{l}\text { dang } \\
\text { kal }\end{array}$ & $\begin{array}{l}\text { meng } \\
\text { hamb } \\
\text { at }\end{array}$ \\
\hline $\mathrm{PH}$ & $5-4$ & $4,5-4$ & 4 & 3 \\
\hline $\begin{array}{l}\text { Administ } \\
\text { rasi }\end{array}$ & Kelas I & $\begin{array}{c}\mathrm{Ke} \\
\text { las } \\
\text { II }\end{array}$ & $\begin{array}{c}\text { Kelas } \\
\text { III }\end{array}$ & $\begin{array}{c}\text { Kel } \\
\text { as } \\
\text { IV }\end{array}$ \\
\hline $\begin{array}{l}\text { Surat_M } \\
\text { enyurat }\end{array}$ & Baik & $\begin{array}{l}\mathrm{Bi} \\
\text { asa }\end{array}$ & $\begin{array}{l}\text { Agak } \\
\text { biasa }\end{array}$ & $\begin{array}{l}\text { Bur } \\
\text { uk }\end{array}$ \\
\hline Hama & Kelas I & $\begin{array}{c}\mathrm{Ke} \\
\text { las } \\
\mathrm{II}\end{array}$ & $\begin{array}{c}\text { Kelas } \\
\text { III }\end{array}$ & $\begin{array}{c}\text { Kel } \\
\text { as } \\
\text { IV }\end{array}$ \\
\hline $\begin{array}{l}\text { Kumban } \\
\text { g_Pengg } \\
\text { erak (\%)/ } \\
\text { hari }\end{array}$ & $0-15$ & $\begin{array}{l}16 \\
- \\
25\end{array}$ & $25-36$ & $>36$ \\
\hline $\begin{array}{l}\text { Tikus } \\
(\%) / \text { hari }\end{array}$ & $0-15$ & $\begin{array}{l}16 \\
- \\
25\end{array}$ & $25-36$ & $>36$ \\
\hline $\begin{array}{l}\text { Rayap } \\
(\%) / \text { hari }\end{array}$ & $0-15$ & $\begin{array}{l}16 \\
-\end{array}$ & $25-36$ & $>36$ \\
\hline
\end{tabular}

Nilai masukan sebenarnya didapatkan dari hasil masukan seluruh data dari tabel kondisi fisik lahan untuk perkebunan kelapa sawit, dimana spisifikasi dari tabel akan memberikan nilai terhadap setiap spisifikasi. Perbandingan kriteria yang di modelkan dengan menggunakan metode pengembangan promethee. Perbandingan nilai kriteria berdasarkan kelas setiap kriteria, nilai setiap kriteria berdasarkan jumlah semua nilai sub- 
sub masing-masing kriteria. Jumlah nilai masing-masing kriteria akan menjadi nilai perhitungan dalam menentukan alternatif rangking. Dalam model ini, setiap sub kriteria akan memiliki nilai masukan yang telah ditentukan sebalumnya berdasarkan kelaskelasnya

Tabel 3. Potensi Produksi Berdasarkan Kelas

\begin{tabular}{|c|c|c|c|c|}
\hline \multirow{4}{*}{$\begin{array}{l}\text { Umur } \\
\text { Tanaman } \\
\text { /Th }\end{array}$} & Kelas & Kelas & Kelas & Kelas \\
\hline & 1 & II & & \\
\hline & (Ton/T & (Ton/T & (Ton/T & (Ton/T \\
\hline & h) & h) & h) & h) \\
\hline 3 & 9 & 7 & 6 & 5 \\
\hline 4 & 17 & 15 & 13 & 10 \\
\hline 5 & 21 & 19 & 16 & 14 \\
\hline 6 & 25 & 22 & 19 & 16 \\
\hline 7 & 28 & 25 & 23 & 19 \\
\hline 8 & 30 & 27 & 25 & 22 \\
\hline 9 & 30 & 27 & 25 & 22 \\
\hline 10 & 30 & 27 & 25 & 22 \\
\hline 11 & 30 & 27 & 25 & 22 \\
\hline 12 & 30 & 27 & 25 & 22 \\
\hline 13 & 30 & 27 & 25 & 22 \\
\hline 14 & 27 & 25 & 23 & 21 \\
\hline 15 & 27 & 25 & 22 & 20 \\
\hline 17 & 25 & 24 & 22 & 20 \\
\hline 18 & 24 & 22 & 20 & 19 \\
\hline 19 & 24 & 22 & 20 & 19 \\
\hline 20 & 22 & 21 & 19 & 18 \\
\hline 21 & 22 & 21 & 19 & 18 \\
\hline 22 & 20 & 19 & 17 & 16 \\
\hline 23 & 20 & 19 & 17 & 16 \\
\hline 24 & 20 & 17 & 16 & 15 \\
\hline 25 & 18 & 17 & 16 & 15 \\
\hline $\begin{array}{l}\text { Rata- } \\
\text { Rata }\end{array}$ & 24 & 22 & 20 & 18 \\
\hline
\end{tabular}

*sumber : Suyatno, 1995, Upaya Meningkatkan Produktivutas Kelap Asawit, Kanisius(Anggota Ikapi), Yogyakarta
Dari tabel diatas maka didapat nilai masing-masing kelas adalah :

a. Nilai masukan pada Kelas I diperoleh jika nilai rata-rata : $(24 / 84) \times 100=29 \%$

b. Nilai masukan pada Kelas II diperoleh jika nilai rata-rata : $(22 / 84) \times 100=26 \%$

c. Nilai masukan pada Kelas III diperoleh jika nilai rata-rata : $(20 / 84) \times 100=24 \%$

d. Nilai masukan pada Kelas IV diperoleh jika nilai rata-rata : $(18 / 84) \times 100=21 \%$ Aturan diatas dapat diringkas sebagai berikut:

a. Kelas $\mathrm{I}=29 \%$

b. Kelas II $=26 \%$

c. Kelas III $=24 \%$

d. Kelas IV $=21 \%$

Dari rancangan nilai yang telah dibuat, maka didapat beberapa kabupaten yang nantinya akan dicari mana kabupaten yang terbaik atau mengurutkan kabupaten yang mana yang lebih baik. Untuk menentukan urutan atau kabupaten mana yang terbaik maka diperlukan perhitungan perbandingan dengan menentukan nilai-nilai perhitungan, Tahapan perhitungan adalah :

Dalam fase pertama, nilai hubungan outrangking berdasarkan pertimbangan dominasi masing-masing kriteria. Indeks preferensi ditentukan dan nilai outrangking secra grafis disajikan berdasarkan preferensi dari pembuat keputusan. Data dasar untuk evalusi dengan metode promethee disajikan sebagai berikut :

Tabel 4. Data Dasar Analisis Promethee

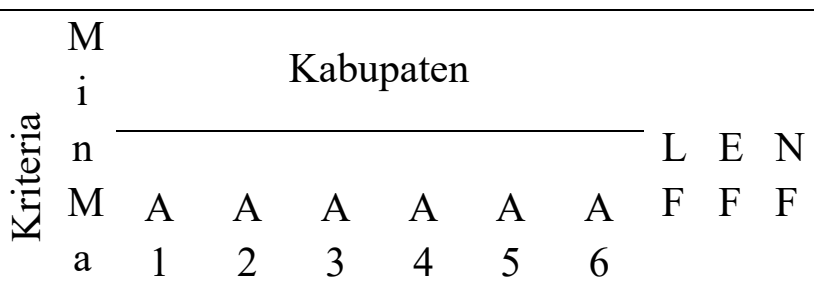

$\mathrm{X}$ 


\begin{tabular}{llllllll}
\hline $\mathrm{K}$ & $\mathrm{M}$ & $\mathrm{K}$ & $\mathrm{K}$ & $\mathrm{K}$ & $\mathrm{K}$ & $\mathrm{K}$ & $\mathrm{K}$ \\
1 & $\mathrm{i}$ & 1( & 1( & 1( & 1( & 1( & 1( \\
$\mathrm{K}$ & $\mathrm{n}$ & $\mathrm{A}$ & $\mathrm{A}$ & $\mathrm{A}$ & $\mathrm{A}$ & $\mathrm{A}$ & $\mathrm{A}$ \\
2 & $\mathrm{M}$ & $1)$ & $2)$ & $3)$ & $4)$ & $5)$ & $6)$ \\
$\mathrm{K}$ & $\mathrm{a}$ & $\mathrm{K}$ & $\mathrm{K}$ & $\mathrm{K}$ & $\mathrm{K}$ & $\mathrm{K}$ & $\mathrm{K}$ \\
3 & $\mathrm{x}$ & 2( & 2( & 2( & 2( & 2( & 2( \\
$\mathrm{K}$ & $\mathrm{M}$ & $\mathrm{A}$ & $\mathrm{A}$ & $\mathrm{A}$ & $\mathrm{A}$ & $\mathrm{A}$ & $\mathrm{A}$ \\
4 & $\mathrm{a}$ & $1)$ & $2)$ & $3)$ & $4)$ & $5)$ & $6)$ \\
$\mathrm{K}$ & $\mathrm{x}$ & $\mathrm{K}$ & $\mathrm{K}$ & $\mathrm{K}$ & $\mathrm{K}$ & $\mathrm{K}$ & $\mathrm{K}$ \\
5 & $\mathrm{M}$ & 3( & 3( & 3( & 3( & 3( & 3( \\
$\mathrm{K}$ & $\mathrm{a}$ & $\mathrm{A}$ & $\mathrm{A}$ & $\mathrm{A}$ & $\mathrm{A}$ & $\mathrm{A}$ & $\mathrm{A}$ \\
6 & $\mathrm{x}$ & $1)$ & $2)$ & $3)$ & $4)$ & $5)$ & $6)$ \\
& $\mathrm{M}$ & $\mathrm{K}$ & $\mathrm{K}$ & $\mathrm{K}$ & $\mathrm{K}$ & $\mathrm{K}$ & $\mathrm{K}$ \\
& $\mathrm{a}$ & 4( & 4( & 4( & 4( & 4( & 4( \\
& $\mathrm{x}$ & $\mathrm{A}$ & $\mathrm{A}$ & $\mathrm{A}$ & $\mathrm{A}$ & $\mathrm{A}$ & $\mathrm{A}$ \\
& $\mathrm{M}$ & $1)$ & $2)$ & $3)$ & $4)$ & $5)$ & $6)$ \\
& $\mathrm{a}$ & $\mathrm{K}$ & $\mathrm{K}$ & $\mathrm{K}$ & $\mathrm{K}$ & $\mathrm{K}$ & $\mathrm{K}$ \\
& $\mathrm{x}$ & 5( & 5( & 5( & 5( & 5( & 5( \\
& & $\mathrm{A}$ & $\mathrm{A}$ & $\mathrm{A}$ & $\mathrm{A}$ & $\mathrm{A}$ & $\mathrm{A}$ \\
& $1)$ & $2)$ & $3)$ & $4)$ & $5)$ & $6)$ \\
& & $\mathrm{K}$ & $\mathrm{K}$ & $\mathrm{K}$ & $\mathrm{K}$ & $\mathrm{K}$ & $\mathrm{K}$ \\
& 6( & 6( & 6( & 6( & 6( & 6( \\
& & $\mathrm{A}$ & $\mathrm{A}$ & $\mathrm{A}$ & $\mathrm{A}$ & $\mathrm{A}$ & $\mathrm{A}$ \\
& & $1)$ & $2)$ & $3)$ & $4)$ & $5)$ & $6)$ \\
\hline & & & $\mathrm{S}$ & & $\mathrm{P}$ & & \\
& &
\end{tabular}

*sumber : Sistem Pendukung Keputusan, Kadarsah, 1998

Berikut ini merupakan penjelasan dari istilah atau singkatan yang digunakan :

1. $\mathrm{K} 1(\mathrm{~A} 1)$ : Elemen matrik $\mathrm{K} 1$ baris ke 1 dan kolom ke 1

2. $\mathrm{K} 1(\mathrm{~A} 2)$ : Elemen matrik $\mathrm{K} 1$ baris ke 1 dan kolom ke 2

3. $\mathrm{K}_{\mathrm{mn}}$ : Elemen matrik $\mathrm{K}$ baris $\mathrm{ke} \mathrm{m}$ dan kolom ke $\mathrm{n}$

Berdasarkan tabel data diatas maka untuk mencari nilai arah dalam persentase outrangking, dengan menggunakan :

1. Jumlah dari nilai garis lengkungan yang memiliki arah menjauh dari node a lebih baik dari x (leaving flow).

2. Diukur berdasarkan karakter outrangking dari nilai a (entering flow)
3. Menentukan perbandingan urutan nilai yang terbaik atau rangking dari kabupaten (net flow).

Seperti yang telah diketahui bahwa nilai yang dimasukan ke dalam matrik merupakan nilai perbandingan berpasangan dimana nilai elemen $K_{m n}$ merupakan nilai kebalikan dari elemen $\mathrm{K}_{\mathrm{nm}}$. Sedangkan untuk elemen matrik yang memiliki nomor baris dan kolom yang sama, misalnya elemen matrik $M$ baris ke 1 dan kolom ke 1 akan bernilai 1. Hal ini dapat terjadi karena elemen matrik yang memiliki baris dan kolom yang sama hanyalah membandingkan kriteria yang sama. Dengan demikian, pengguna atau user aplikasi ini yaitu admin tidak perlu memasukkan seluruh nilai elemen matrik.

Dalam fase kedua, dalam proses penentuan prioritas adalah menjumlahkan nilai dari setiap kolom matrik. Aturan yang dapat dipakai sebagai berikut :

Sebelum menghitung nilai setiap kolom maka kata harus menentukan daerah mana yang akan dibandingkan :

Tahap I :

Daerah A1 di bandingkan dengan daerah A2

Tahap II :

$$
\begin{aligned}
& \text { Untuk K1 } \\
& \mathrm{d}=\mathrm{A} 1-\mathrm{A} 2
\end{aligned}
$$

Tahap III :

kemudian menentukan kaidah yang akan digunakan, yaitu maksimasi atau minimasi

$$
\begin{aligned}
& \mathrm{P}(\mathrm{A} 1, \mathrm{~A} 2)=\mathrm{a} \\
& \mathrm{P}(\mathrm{A} 2, \mathrm{~A} 1)=\mathrm{b}
\end{aligned}
$$

Tahap IV :

Menghitung semua nilai yang terdapat

$$
\begin{aligned}
& \wp(\mathrm{A} 1, \mathrm{~A} 2)=1 / 6 * \sum(A 1, A 2) \\
& \wp \mathrm{P}(\mathrm{A} 2, \mathrm{~A} 1)=1 / 6 * \sum(A 2, A 1)
\end{aligned}
$$




$$
\begin{aligned}
& \text { leaving flow: } \Phi^{+}(\mathrm{a})=\frac{1}{\mathrm{n}-1} \sum_{\mathrm{x} \varepsilon \mathrm{A}} \wp(\mathrm{a}, \mathrm{x}) \\
& \text { entering flow: } \Phi^{-}(\mathrm{a})=\frac{1}{\mathrm{n}-1} \sum_{\mathrm{x} \varepsilon \mathrm{A}} \wp(\mathrm{x}, \mathrm{a}) \\
& \text { net flow: } \Phi^{+}(\mathrm{a})-\Phi^{-} \text {(a) }
\end{aligned}
$$

\section{Perancangan Proses}

Rancangan Diagram Alir Data (DAD) pada penentuan daerah tanam kelapa sawit dengan metode promethee adalah sebagai berikut:

\section{DAD Level 0}

DAD level 0 memberikan gambaran seluruh elemen sistem. Terdapat dua entitas yaitu admin dan user. user memiliki akses untuk memilih kabupaten dan mendapatkan laporannya dari pilihan yang dimasukkan user, sedangkan admin mempunyai akses untuk melakukan pengelolaan data kriteria optional, data kriteria utama, kriteria, dan nilai preferensi. Gambar DAD level 0 sebagai berikut:

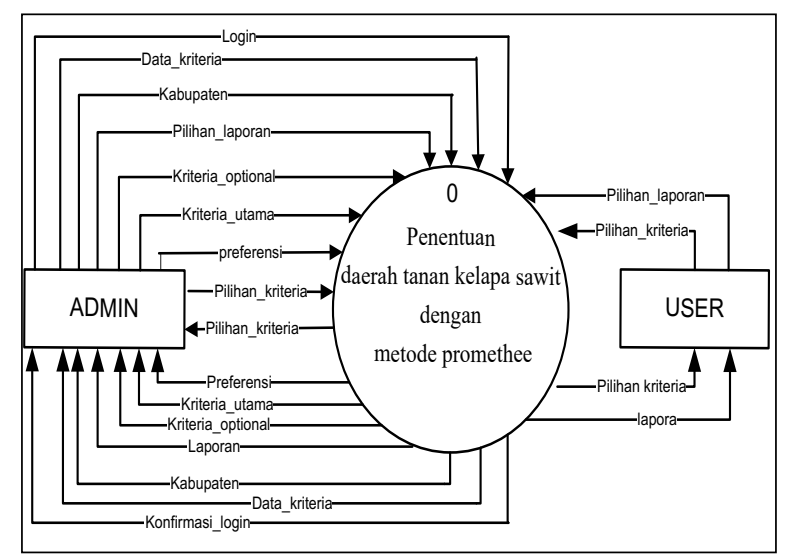

Gambar 3. DAD Level 0

\section{DAD Level 1}

Pada diagram level 1 penentuan daerah tanam kelapa sawit dengan metode promethee dibagi menjadi tiga proses, yaitu login, olah data perhitungan. DAD level 1.1 dapat dilihat pada gambar berikut:

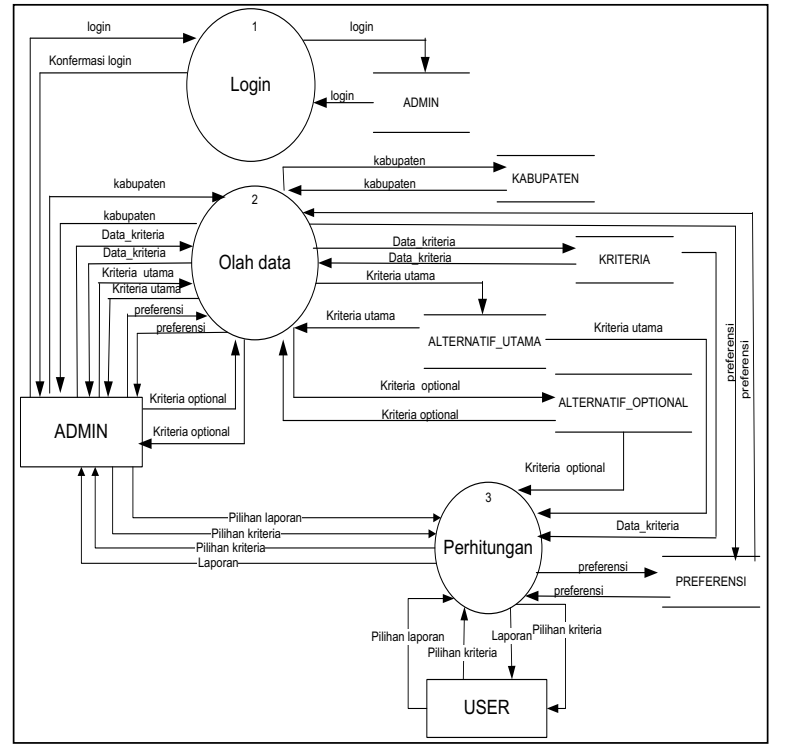

Gambar 4. DAD Level 1.1

3. DAD Level 2.2 Proses olah data

Proses olah data dibagi menjadi lima proses, yaitu kriteria, kabupaten, kriteria utama, kriteria optional, dan preferensi. Admin melakukan pengolahan data berdasarkan nilai masing-masing kabupaten dan kriteria yang telah ditentukan. Admin memasukkan data yang telah ditentukan sebelumnya kedalam tabel berdasarkan tabeltabel yang telah ditentukan. Gambar DAD level 2.2 proses olah data sebagai berikut: 


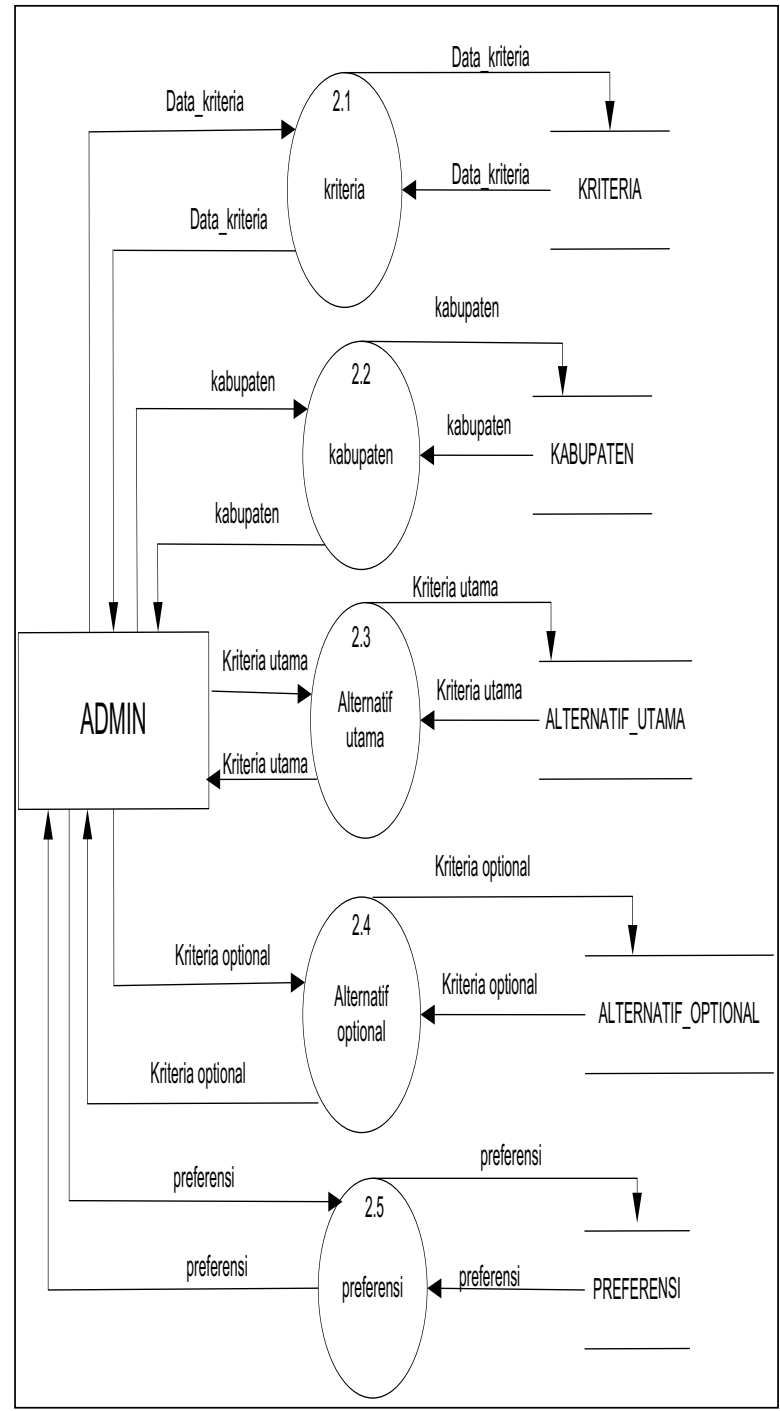

Gambar 5. DAD Level 2.2 Proses Olah Data

\section{DAD Level 2.3 Proses Perhitungan}

Proses olah data dibagi menjadi dua proses, yaitu perhitungan preferensi dan menampilkan. Admin melakukan proses perhitungan berdasarkan nilai masing-masing kabupaten dan kriteria serta dapat melihat atau menampilkan data. sedangkan user hanya mendaptkan hasil dari perhitungan. Gambar DAD level 2.3 proses perhitungan sebagai berikut:

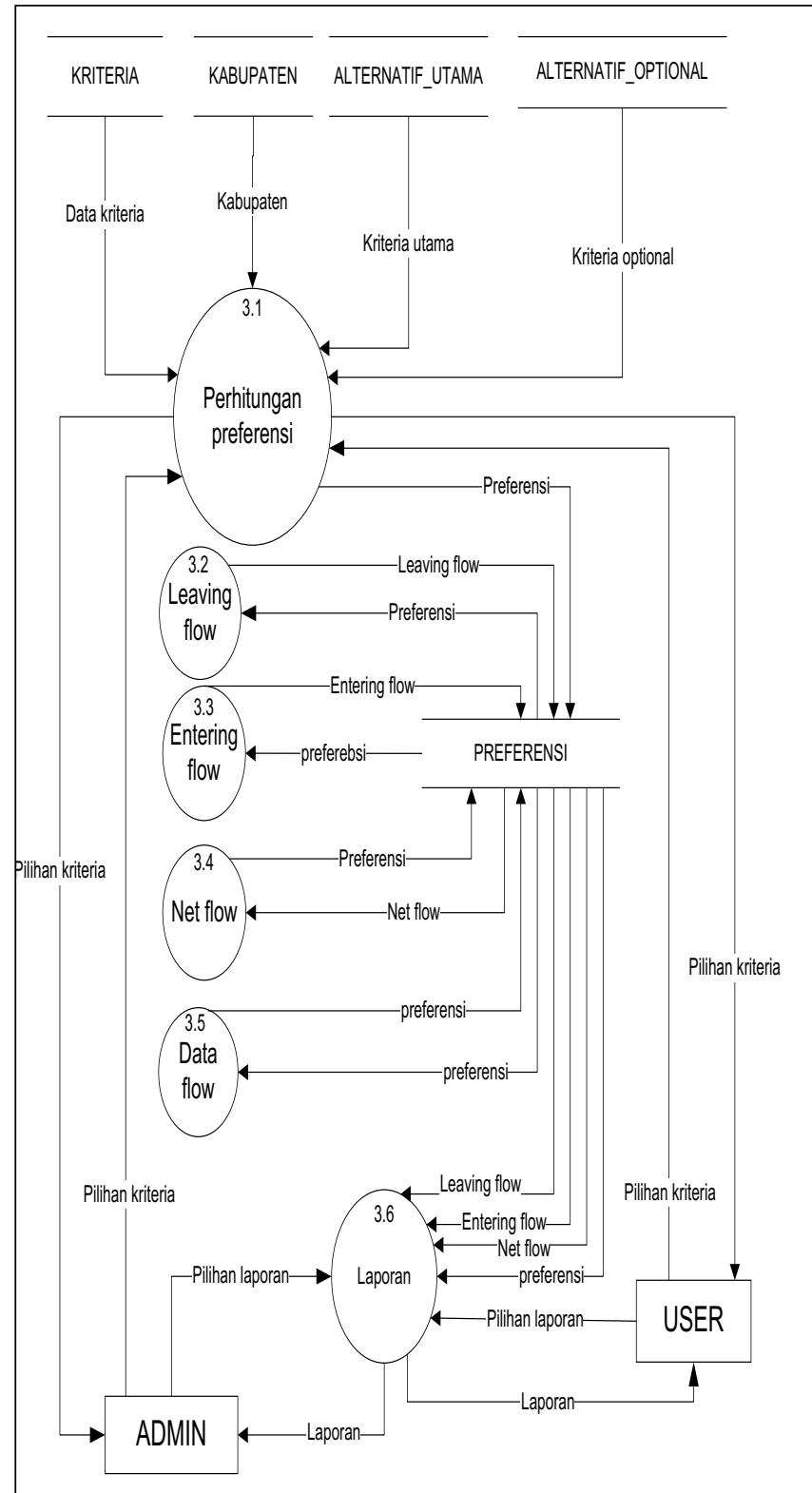

Gambar 6. DAD Level 2.3 Proses Perhitungan

\section{Perancangan Flowchart}

Perhitungan promethee dapat dilihat dengan struktur program flowchart, proses perhitungannya, yaitu : Nilai preferensi, data flow, leaving flow, entering flow, dan net flow. Bagan alir program (flowchart) adalah suatu bagan yang menggambarkan arus logika dari data yang akan diproses dalam suatu program dari awal sampai akhir. 


\section{Flowchart Nilai preferensi}

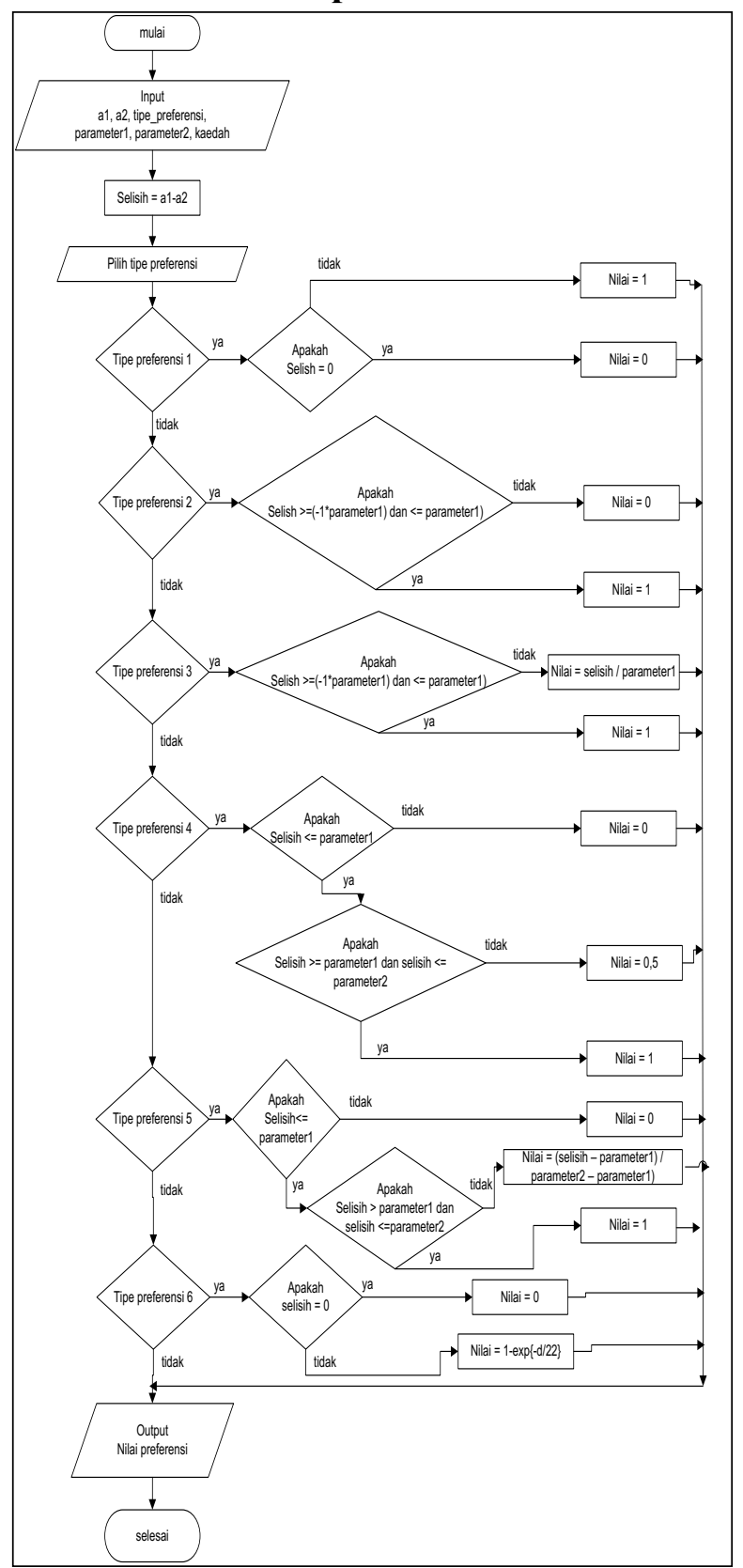

Gambar 7. Flowchart Nilai preferensi

Admin memasukkan data preferensi, kemudian data tersebut dihitung selisih al dan a2, jika benar nilai benar akan memilih tipe preferensi satu sampe 5, jika salah nilai salah akan melakukan perhitungan ulang. Setelah melakukan perhitungan berdasarkan tipe preferensi yang dipilh maka akan mendapatkan nilai preferensi.

\section{Flowchart Data Flow}

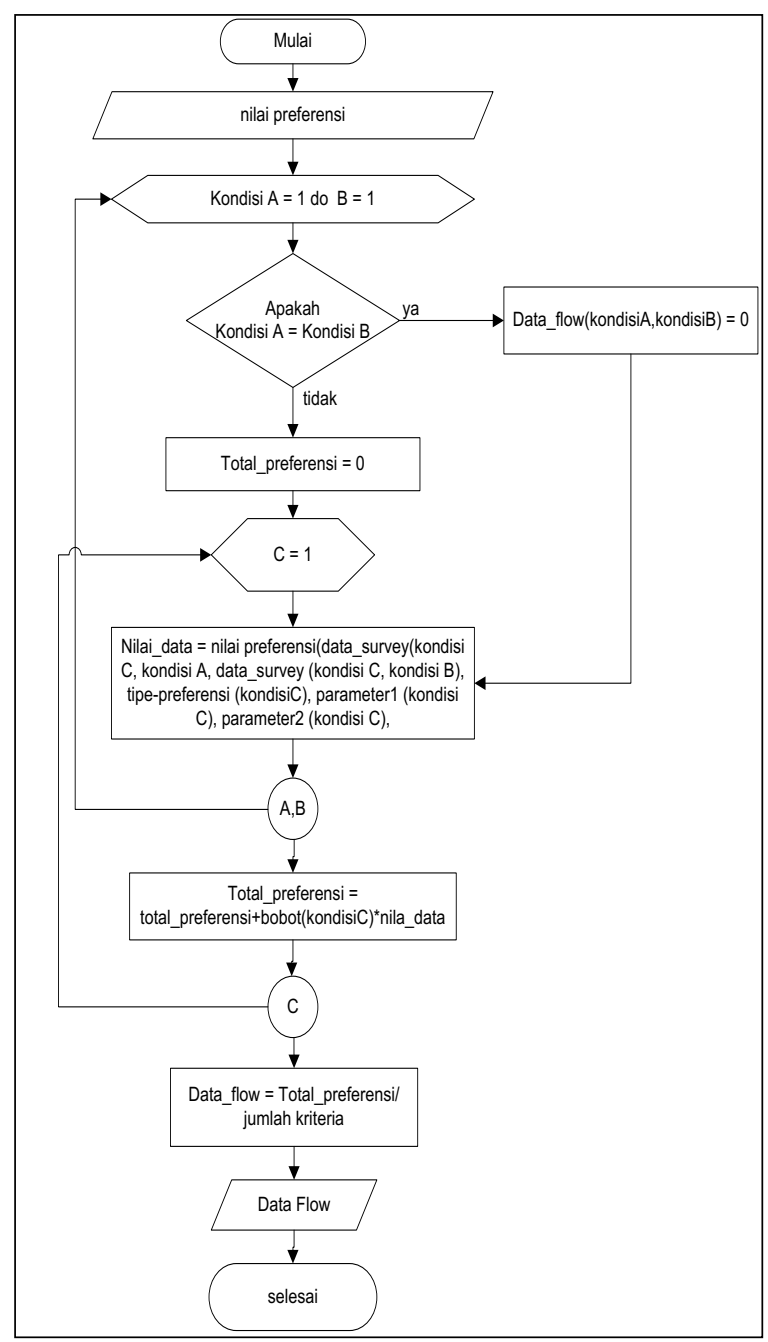

Gambar 8. Flowchart data flow

Admin memasukkan data preferensi, kemudian data tersebut mendapatkan nlai awal dan akhir, kemudian apakah nilai tersebut sama, jika nilai tersebut sama maka akan mendapatkan data flow (kondisi A,B) adalah 0 , jika tidak maka total preferensi 0 dan akan melanjutkan perhitungan nilai dari data tersebut, kemudian akan mendapatkan total preferensi dari hasil perhitungan Total_preferensi = total_preferensi + bobot(kondisiC) * nila_data, untuk mendapatkan data flow maka Total_preferensi dibagi enam dan mendapatkan hasil akhir data flow. 


\section{Flowchart Leaving Flow}

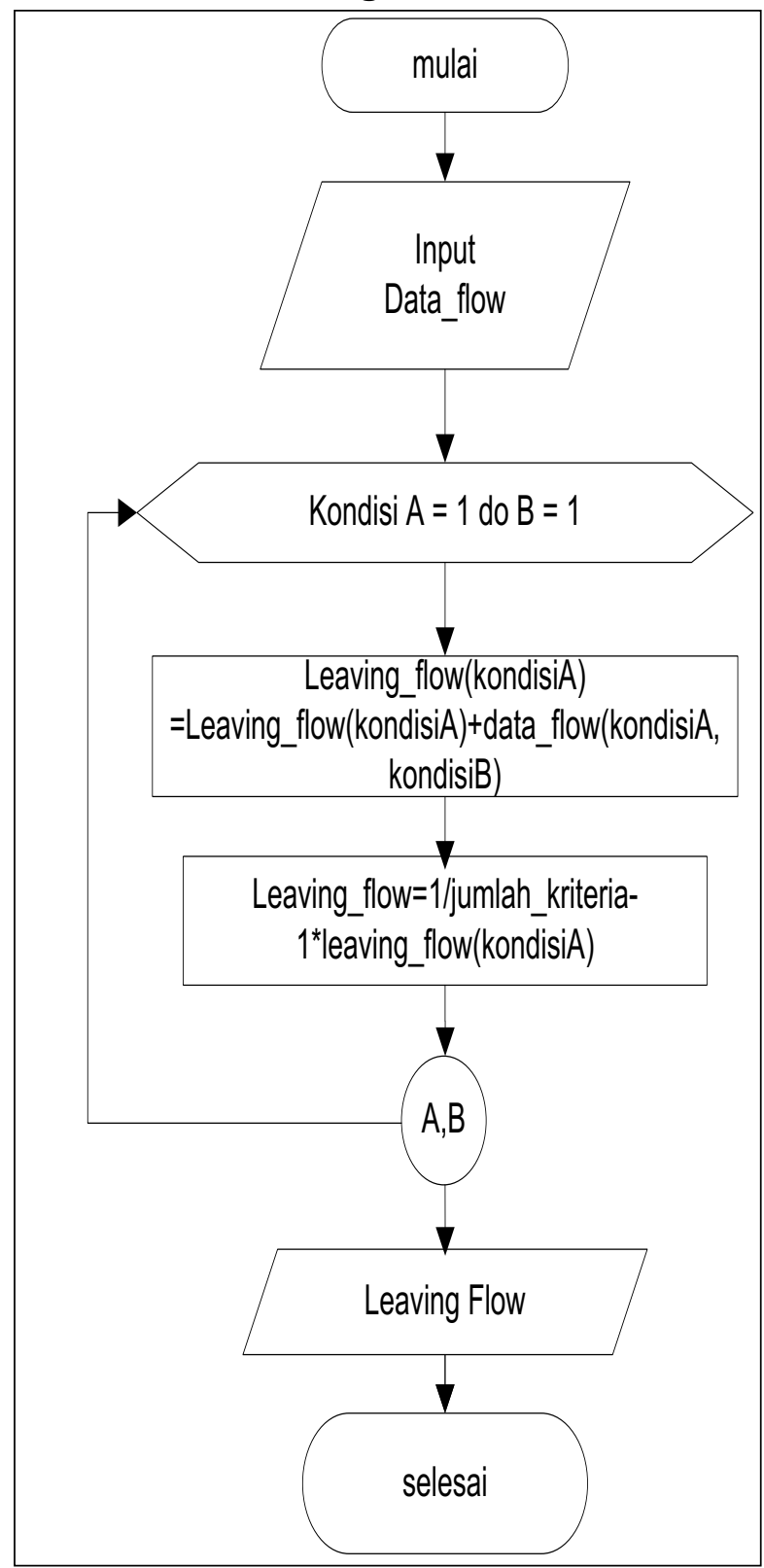

Gambar 9. Flowchart leaving flow

Admin memasukkan data flow, kemudian data tersebut mendapatkan nlai awal dan akhir, kemudian memproses leaving flow kondisi A, setelah mendapatkan nilai leaving flow konsis A maka akan melakukan perhitungan Leaving flow dan menyimpannya berupa nilai leaving flow.

\section{Flowchart Entering Flow}

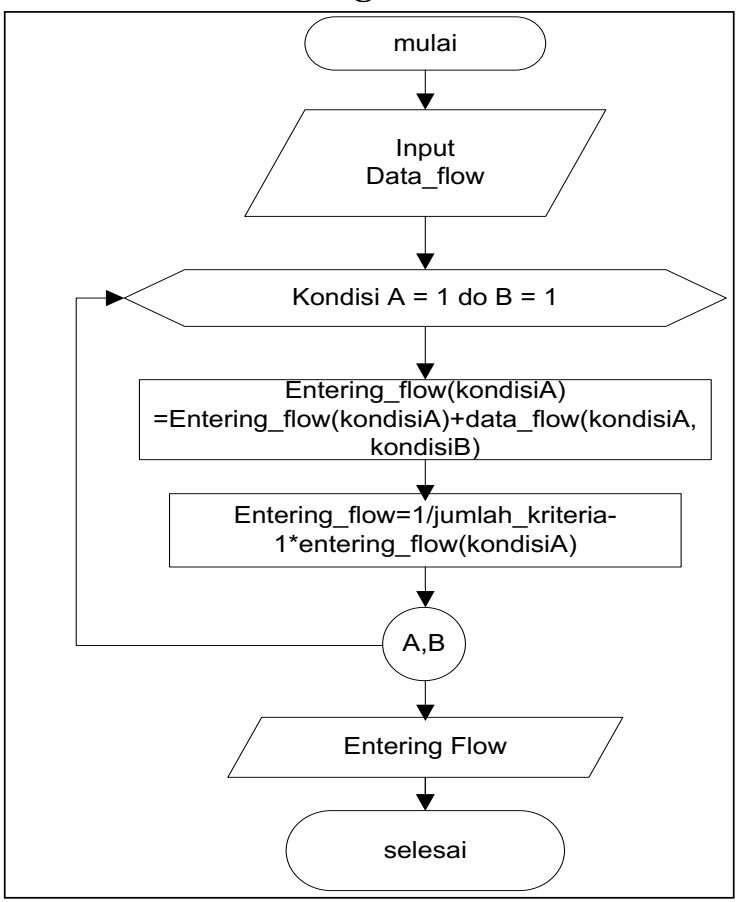

Gambar 10. Flowchart entering flow

Admin memasukkan data flow, kemudian data tersebut mendapatkan nlai awal dan akhir, kemudian memproses entering flow kondisi A, setelah mendapatkan nilai entering flow konsis A maka akan melakukan perhitungan entering flow dan menyimpannya berupa nilai entering flow.

\section{Flowchart Net Flow}

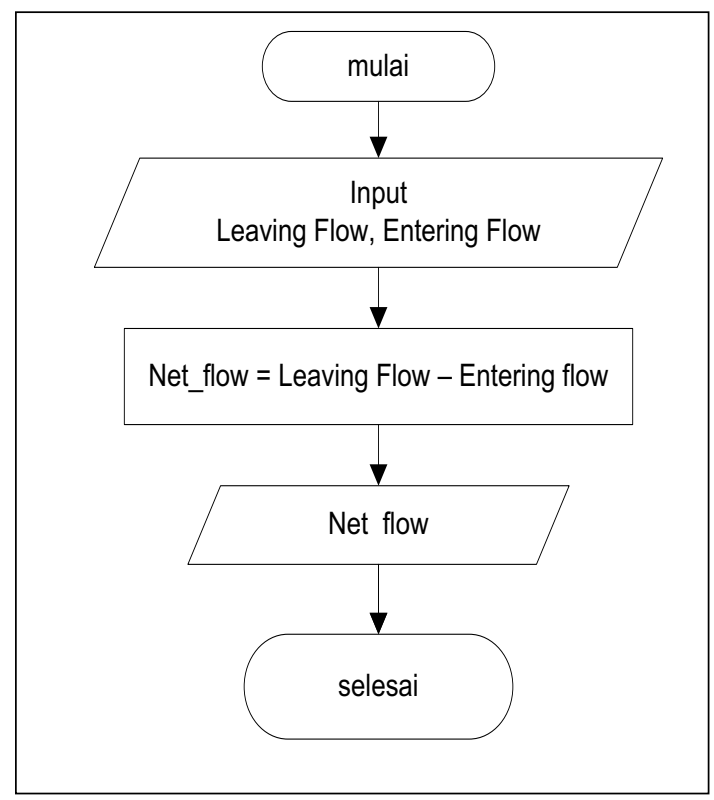




\section{RABIT : Jurnal Teknologi dan Sistem Informasi Univrab}

Volume 1 No. 2 | Juli 2016 : 78-97

Gambar 11. Flowchart net flow

Admin memasukkan data leaving flow dan entering flow, kemudian melakukan perhitungan net flow dan menyimpan nilai tersbut berupa nilai net flow

\section{Halaman home}

Berikut adalah halaaman home yang terdiri dari beberapa menu yaitu : pilihan kriteria, data flow, data survey, rangking, help, cetak, persentase, peta riau, pencarian data, dan login. Halaman ini berfungsi sebagai menu utama dari user.

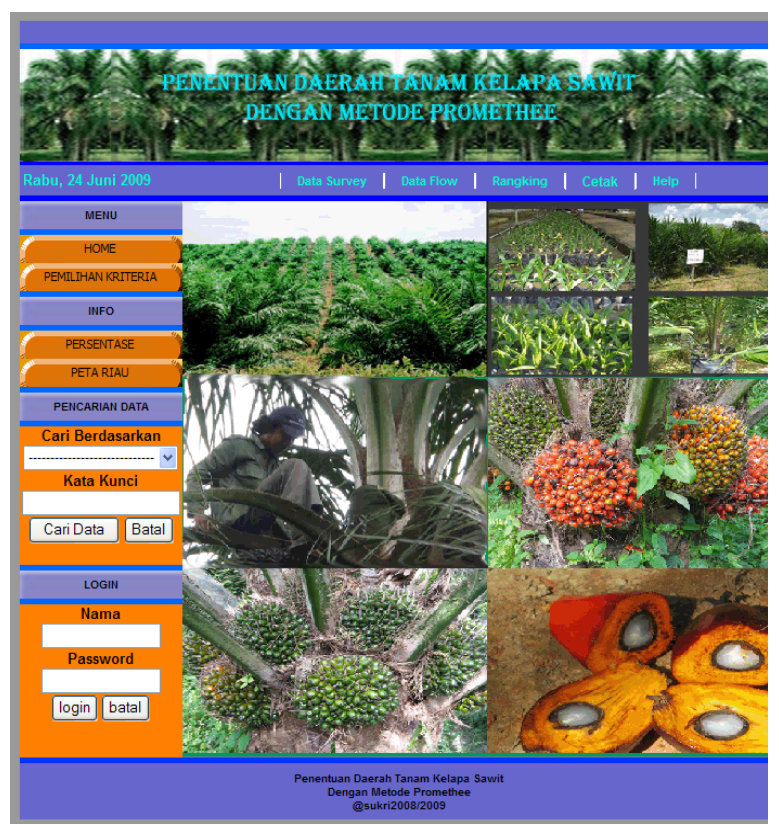

Gambar 12. Tampilan Home User

\section{Halaman Pilihan Kriteria}

Halaman pilihan kriteria berfungsi untuk memilih data kriteria utama dan kriteria optional oleh user dengan menceklis bagian yang diinginkan user untuk mendapatkan hasil proses promethee.

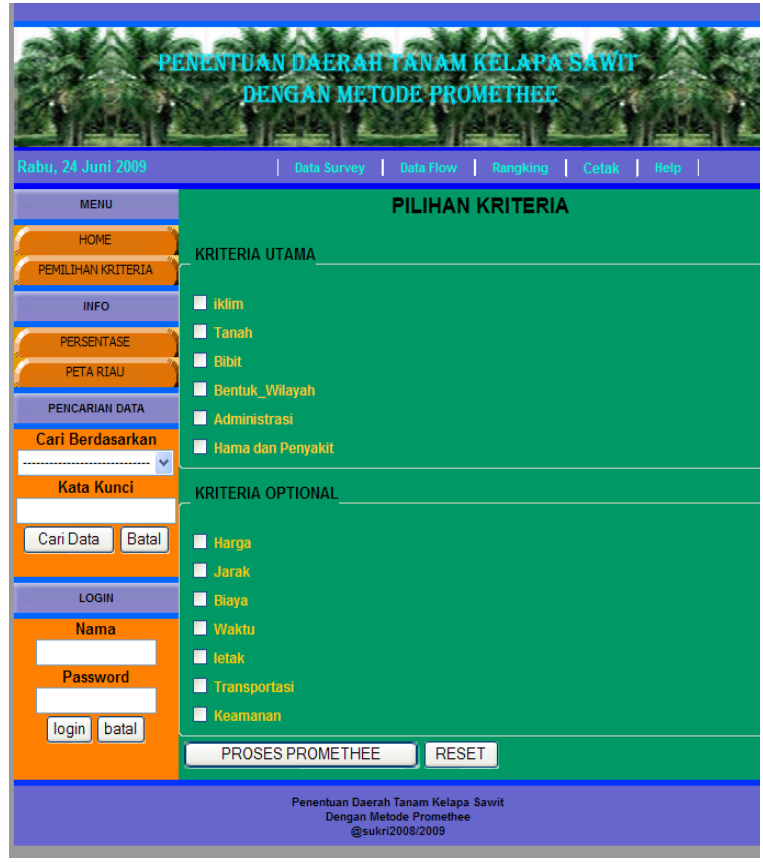

Gambar 13. Tampilan Pilihan Kriteria

\section{Halaman Persentase}

Tampilan Persentase hanya berfungsi untuk menampilkan persentase dari nilai score dari proses promethee yang di inputkan melalui pilihan kriteria.

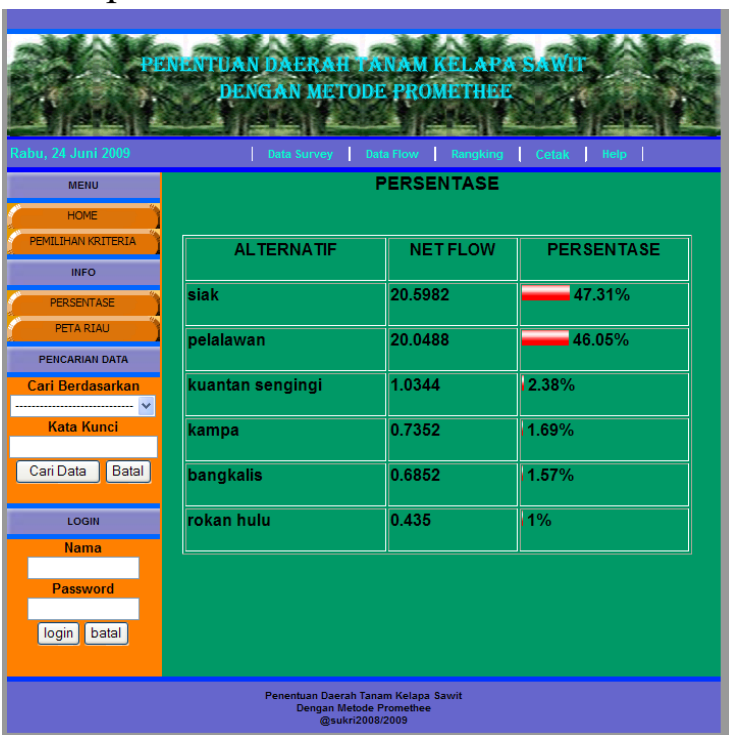

Gambar 14. Tampilan Persentase

\section{KESIMPULAN}

Hasil kesimpulan yang dapat diambil dari penyusunan tugas akhir ini adalah :

1. Dengan bantuan suatu model sistem pendukung keputusan, dalam hal ini 
metode promethee maka para petani kelapa sawit dapat memperoleh informasi alternatif daerah tanam kelapa sawit yang cocok dan menghasilkan produktifitas yang maksimal bagi User (para petani) secara cepat.

2. Dengan sistem pendukung keputusan dapat ditentukan keputusan yang objektif. Keputusan (Rangking) yang dihasilkan dari sistem pendukung keputusan untuk memilih wilayah tanam kelapa sawit denagn metode promethee bukan lah suatu keputusan (Rangking) yang mutlak dimana keputusan akhir tetap ditentukan sendiri oleh User..

3. Dengan metode promethee dapat ditentukan urutan (prioritas) dalam analisis multikriteria. Dengan masalah pokoknya adalah kesederhanaan, kejelasan, dan kestabilan.

\section{DAFTAR PUSTAKA}

[1]. Betha, 2006, Pemrograman Web dengan PHP, Penerbit Informatika, Bandung

[2]. Bimo, 2003, PHP dan MySQL untuk $W e b$, Penerbit Andi, Jogjakarta

[3]. Daihani, Dadan Umar, 2001, Komputerisasi Pengambilan Keputusan, Elex Media Komputindo, Jakarta

[4]. Fathansyah, Ir, 1999, Basis Data, Informatika, Bandung

[5]. Hartono, Jogiyanto, 1999, Pengenalan Komputer, Andi Offset, Yogyakarta

[6]. Kadarsah, 1998, sistem pendukung keputusan, pt.ramaja rosdakarya, bandung
[7]. Kadir, Abdul, 2002, Pengenalan Sistem Informasi, Penerbit Andi, Yogyakarta

[8]. Kristanto, Andri, 2004, Rekayasa Perangkat Lunak (Konsep Dasar), Gava Media, Yogyakarta

[9]. Lenawati, Mei, 2007, Dreamweaver 8 dengan PHP, Penerbit Andi Ofset, Madiun.

[10]. Nugroho, Munafit, 2006, Tips Dan Trik Pemograman Php5, Ardana Media, Yogyakarta

[11]. Pressman, Rogers, 1997, Rekayasa Perangkat Lunak: Pendekatan Praktisi, Andi Offset, Yogyakarta.

[12]. Pressman, R.S, 2000, Rekayasa Perangkat Lunak, Penerbit Andi, Yogyakarta

[13]. Riwandi, 2002, Hasil penelitian laboratorium ilmu tanah jurusan budidaya pertanian fakultas pertanian UNIB.

[14]. Suryadi, Kadarsah Dkk, 2002, Sistem Pendukung Keputusan, Rosda, Bandung

[15]. Suyatno, 1995, Upaya Meningkatkan Produktivutas Kelap Asawit, Kanisius(Anggota Ikapi), Yogyakarta

[16]. Syafii, M, 2004, Membangun Aplikasi Berbasis Php Dan Mysql, Andi Offset, Yogyakarta

[17]. Tavri, D, 1991, Pengantar Analisis Dan Perancangan Perangkat Lunak, Elex Media Komputindo, Jakarta

[18]. Turban, 2005, Decision Support Systems And Intelligent Systems (Sistem Pendukung Keputusan Dan Sistem Cerdas), Jilid 1, Edisi 7, Andi, Yogyakarta. 